\title{
A TREE-BREEDING PROGRAM FOR CANADA
}

\author{
BY I. C. M. PLACE 1
}

Why a Tree-Breeding Program?

Tree breeding entails lengthy research, and for this reason many foresters are inclined to dismiss it as being impractical at the present time. The writer believes this to be a mistake: the matter is urgent, and the time to tackle it is now.

Let us consider Canada's stake in her forests. Some 350,000 Canadians are directly dependent upon the payrolls of the forest industries. It is estimated that the net annual value of the forest products in 1948 was equivalent to $\$ 107$. per capita; about $\$ 11$. out of every $\$ 100$. of Canadian income are derived from our forests. In 1948, the sale of forest products accounted for one-third of the value of Canada's exports. Canada's continued prosperity depends greatly upon the existence of productive forests.

Excluding the Northwest and Yukon Territories and Newfoundland, almost 60 per cent of Canada is forest land, but little more than half of this is classed as productive. Vast stretches have been burned repeatedly and have no adequate seed supply to ensure regeneration even if seedbeds were favourable. In 1948, fires burned over 16,000 square miles of forest land in Ontario alone (Dom. For. Serv., 1949); one burn in northern New Brunswick covered more than 300 square miles of forest land, only 5 to 10 per cent of which is regenerating to conifers. How is such land to be made productive? Planting or seeding seems to be the only answer.

Besides land which is actually idle, much more land is unproductive in that it supports stands which will never have a commercial value. This includes many stands of aspen, birch and cherry of fire origin, growing on sites not rich enough for good hardwoods. Many cut-over forests of northern hardwoods also come in this category; all too often the second-growth stands show little promise of having much worth in the next rotation. It might be possible to convert some of these areas to valuable softwoods for a rotation. But again planting would be necessary.

In many localities farming in Canada is only made possible by money from farm woodlots. Moreover, the pulp and paper industry depends upon these woodlots for much of its wood. Great opportunities exist here for intensive management and establishment of plantations. But it is not easy to sell good forestry or planting to a small woodland owner who knows he may not live to profit from his investment. Extension forestry urgently needs strong selling points; better trees might be an answer.

Planting means investment of money for a long period. Cutting even 10 years off the time it takes to grow a crop of pulpwood would mean a saving of 30 to 40 per cent in one rotation. Judging from what has already been done with some hybrids, this is a modest estimate of what may be accomplished.

- Forestry Branch. Department of Resources and Development, Ottawa 
Objections are raised to tree breeding because of the time it takes. It is true that forest tree breeding must usually precede the actual demand for new types by 10 or 20 years, but this is really an argument in its favour on the ground of future needs. Apparently it is not generally realized that many agricultural crops take equally long to develop. Stockwell and Righter (1947) have developed a cogent argument based upon the differences in breeding trees and field crops. They point out that in breeding field crops, genetic uniformity is essential. Lack of uniformity in his crops would ruin the modern farmer and long carefully conducted field trials are necessary to ensure it. This is not so with trees.

Timbermen are accustomed to using trees of natural origin and variability does not disturb them. The forest planter only expects to harvest 200 or 300 mature trees per acre out of an original stock of 1200 or more. New trees can be planted at suitable intervals in a plantation; if the new strain is inferior to the standard planting stock, it will be crowded out before maturity; if it is superior it will crowd out the standard stock and occupy the site at maturity. In either event the planter does not stand to lose a crop.

Another objection raised against use of hybrids is that although the first generation $\left(F_{1}\right)$ hybrids may be superior to standard strains, the $F_{2}$ hybrids will be useless and the entire area will need replanting; whereas if a standard strain were used, the area would regenerate itself naturally. Supposing the hybrids are fertile, as most conifer hybrids are, nearly 50 per cent of the $F_{2}$ plants will be as good as the $F_{1}$ 's and a few will be even better. A stand of $\mathrm{F}_{2}$ hybrids would contain enough good trees to stock the area adequately and crowd out worthless stems (Stockwell et al, 1947). The problem does not even arise with species such as aspens, which can be regenerated vegetatively from root suckers.

Apart from the planting aspects, forest practice is gradually becoming more intensive. Competition and increasing scarcity of accessible supplies of high quality wood will accentuate this trend. World demand for wood products may be nearly insatiable, but not at the prices at which we are producing them. Technological improvements in logging and manufacture cannot compensate indefinitely for mounting costs of transportation and labor and an increasingly poor grade of raw material.

The Scandinavians are already growing better timber and underselling us; and, as Russia's transport facilities improve, we can expect more and more Russian timber and pulp to be dumped on the world market. Research in wood chemistry is making possible manufacture of pulp from many hitherto unsuitable species in the United States. Finally, wood substitutes are pushing timber out of many fields of construction simply because of the high cost of good lumber. Eventually the forest industries must meet these challenges by growing better wood nearer the mills. This means better silviculture.

Intensive forestry could be practised readily over much of the land area of Canada. The Maritime Provinces, the Eastern Townships of Quebec, and southern Ontario may be cited as examples. The forests are moderately accessible, growth is fairly good, and (as compared with central and northern 
Europe) reproduction is easy to secure. However, information is badly needed to enable accurate selection of trees to be made for natural regeneration. Experimental breeding is the only way to acquire a knowledge of inherent characteristics of trees and the mode of their inheritance.

Aside from all other considerations, the need for starting a program now is urgent from the standpoint of preserving existing genetic values. The current trend in the pulp and paper industry is towards partial cutting. In its first manifestations, this almost invariably takes the form of rough diameter limit cuttings. Under the plea of expediency, the largest and best stems are taken first; diseased and slow-growing trees are left as parents of the coming crop, and the genetic value of succeeding crops gradually becomes poorer. For over a century we have been harvesting our best trees; many areas have been cut over three times; extensive stands of virgin growth in south-eastern Canada are well-nigh impossible to find. It ought to be apparent to all thinking foresters that some genetic impoverishment has taken place. This trend must be reversed; genes once gone are, for practical purposes, lost forever (Brink 1949).

\section{OUTLINE FOR RESEARCH}

Space permits presentation of only the barest outline of a plan for tree breeding. The writer is not a professional geneticist and the following program is not original; it is substantially that indicated in part by many authorities, among whom Johnson (1939), Heimburger (1947), Lindquist (1948), Brink (1949), and Schreiner (1950) may be mentioned. I am especially indebted to the last three authors.

A plan for tree breeding may logically follow along these lines:

(1) improving the genetic quality of the seed now in use;

(2) segregating and evaluating inherently superior trees and races in the wild population;

(3) breeding new types.

These avenues of research complement one another and to some extent proceed concurrently, but for the sake of convenience are here discussed under separate headings.

Improving the Genetic Quality of the Seed

The first step in improving the genetic quality of the seed is to use only the best trees in the best stands as sources of supply. This entails compiling an inventory of potential sources. The larger limit holders and provincial forest services could assist greatly in this task. It might be made an integral part of cruising to classify stands as 'plus', 'normal', or 'minus' for seed collection. Preliminary studies to provide criteria for such classification ought to start immediately. Efforts should then be made to restrict seed collecting to the best trees in the 'plus' stands and to sample as many of these as possible before they are cut.

The Crown ought to acquire some stands of outstanding excellence which are isolated from poor trees and reserve them for seed orchards. These ought to be scattered throughout each major forest region so that seed of local 
origin could be provided for any district. Treatment of orchards would aim at eliminating any poor stems and stimulating crown development for maximum seed production.

For a number of reasons, one generation of such selection could be expected to shift the average quality of the stock only slightly above that of the general population. However, as Brink (1949) points out, at present seed collectors are paid for quantity rather than quality; naturally they favor trees on which the crop is abundant and easily reached; this often means that seed is taken from low, heavy-branched individuals which are sometimes slow growers also. The seed is thus of lower quality than the average being produced by existing populations. To such gains, therefore, as would result from using the best trees in the best stands must be added improvement coming from arresting the negative selection element in current collecting procedure.

Segregation and Evaluation of Inberently Superior Trees and Races

Under this heading are included progeny testing and establishing graft plantations. Progeny testing is an indispensable tool in tree breeding (Brink, 1949). The character of the offspring reveals the makeup of the parent. The purpose of progeny testing is to discover individual trees with inherent capacity to give superior offspring when crossed with various other genotypes. This can best be measured when the tree under test is pollinated by a random sample of pollen from many trees around it (ibid). Briefly, the procedure is to gather open pollinated seeds from the few potentially elite specimens; grow the seedlings by families in the nursery, and set out suitably replicated plantations in which the several progeny may be compared with one another and with a random sample of the population from which they come.

Parallel with progeny testing, graft plantations ought to be established to grow clones from the originally selected superior trees. This would enable much more precise evaluation of the phenotype of the original trees and ultimately the plantations would serve as seed orchards where elite clones would inter-pollinate. Once particular trees which showed superior transmitting ability were identified, the graft plantations could be thinned to elite specimens and used for source material for more plantations.

\section{BREEDING NEW TyPES}

Breeding new types entails using the best germ plasm available in the wild population for selective breeding, and making the best possible use of natural and induced polyploidy (Schreiner, 1950).

The range of possibilities is great, the techniques are many and intricate, and the course taken depends upon the objectives. To mention some of the possibilities, breeding may be for fast growth, for high-density wood, for long fibre, or for resistance to frost, specific insects, or diseases. A fast rate of growth is a very important factor in the economics of reforestation and would no doubt be one of the first goals. Hybrid trees probably offer the most immediate prospect of attaining this objective.

Hybrids vigour has been reported for first generation hybrids in a number of genera. Schreiner (1950) indicates that many combinations of desirable 
characteristics can be obtained literally at 'one jump'. In any event crossable species, varieties or other categories of plants usually occur in different localities. Otherwise they would eventually blend into a common type. Thus, even where hybrid vigour is lacking, hybrids are usually intermediate between the parents in rate of growth and other quantitative qualities and can be used to advantage in the region where the slower parent grows.

To paraphrase Brink (1949), tree breeding is long-term research which requires a broad basis for continuing progress. This calls for anticipation of what materials the geneticist will need over decades and the taking of steps now to provide them. It means building up comprehensive collections of trees of known or prospective value for each forest region. Eventually these collections should compromise representatives of, (a) the forest trees native to the region, (b) closely related species occurring elsewhere, (c) exotic species which might be adapted through breeding. The stocks should be dispersed in conformity with soil and climate and to avoid loss in the event of fire. Establishment of such genetical arboretums ties in with the previously mentioned need to conserve genetic values in the face of shrinkage here and abroad.

\section{The FIRST Steps}

How is this program to be implemented? Canada is woefully short of geneticists trained for tree breeding but those few interested have accomplished much. Staff of the Federal Forestry Branch, the Experimental Farms Service, and the National Research Council have developed many hybrid poplars. The Ontario Department of Lands and Forests is conducting a systematic program along the lines indicated in this paper to develop white pine resistant to blister rust, and is also experimenting with hybrid poplars. The Committee on Dutch Elm Disease is endeavouring to produce a resistant strain of elm. The Federal Forestry Branch is starting a program in which efforts will be concentrated on spruce and two-needled pines.

On the Prairies, the Experimental Farms Service is working on four genera: Populus, Pinus, Picea and Caragana. The desirable characteristics in poplar are vigour, frost hardiness, rooting capacity, and resistance to rust and canker. About 100 promising clones are being propagated. The work with spruce is concerned mostly with selection of seed trees; high seed production is one of the factors sought (National Research Council, 1950).

In the writer's opinion, however, the effort being expended is not commensurate with the task and is being too widely dispersed. In view of the existing lack of technicians emphasis for the present should probably be laid on the first two phases of the program, namely, improving the genetic quality of the seed in use and seeking to identify superior races and individuals. Many foresters on the research staffs of the various governments are competent to assist in laying this groundwork for the benefit of specialists.

Such work needs direction and co-ordination. A clearing-house of genetical information should be established. It should be the repository of duplicate records of the location of all 'plus' stands and elite trees; it should receive the results of all genetical research across the country, and be re- 
sponsible for its dissemination. The clearing house should possess detailed information about the local climates where research is being conducted; it could thus arrange suitable exchanges of seed and act as liaison with the International Union of Forest Research Organizations in trading our seed for that of good races of potentially suitable European and Asiatic species; it might assist regional research teams in formulating their plans, offering detailed information about techniques, and helping to eliminate needless duplication of work.

Trained men and the necessary money are not apt to be plentiful enough to allow intensive work on more than a few species simultaneously. Initially, research ought to be concentrated in the more accessible portions of the forested areas where intensive forestry is most practicable and the danger of genetic impoverishment greatest. An analysis of regional needs will have to be made to decide which species will receive priority.

The fundamental research will be both costly and lengthy, and would certainly require support by all levels of government and by universities. The provincial sphere of responsibility is logically the classification of stands as seed orchards, in ensuring that such stands are the seed sources for provincial nurseries, and in setting aside and protecting areas for seed orchards. Seed originating from such orchards might be certified. The provinces might also accomplish much by instituting rigorous grading of nursery stock. Studies in Sweden have shown that even in nursery plants progeny of branchy trees show a tendency towards development of strong side branches (Lindquist, 1948).

The wholehearted assistance of private foresters would do much to speed progress. They know their own lands best and could render valuable help by reporting any very exceptional stands or trees and by reserving them from logging until seed and cuttings could be obtained from them. They might also enable large-scale collection of good seed by timing some of their operations in their best stands for the autumn when seed is ripe. Their co-operation would be essential in making practical use of the results of tree-breeding research.

The problem of staff for the more technical aspects of tree breeding is difficult; the long-term research involved must have continuity of personnel. Although a few highly skilled specialists might well be brought in to start the program, it would be desirable to train young Canadians who would live to see much of the work to completion-if such work can ever be said to be complete. Both governments and industry would do well to offer scholarships to outstanding students for post-graduate study in this field.

The forest school could assist materially by giving enough lectures in forest genetics to make the average students aware of the relation between genetics and good forestry practice. An alert body of foresters in private employment is essential if research is to progress rapidly, and its findings are to be put to the best advantage.

\section{SUMMARY}

A program of tree breeding is needed in Canada to provide criteria 
to enable good silviculture, to provide superior trees to make planting of idle land financially attractive, and to conserve genetic values.

A plan is proposed which entails improving the genetic quality of seed now in use, identifying and evaluating superior trees and races, and breeding new types.

For the present, lack of technicians forces emphasis upon the first two phases of the program. Integration of the efforts of the Federal and Provincial governments and the assistance of private forestry are needed. Outstanding students ought to be encouraged to take post-graduate study in tree breeding.

\section{Literature Cited}

1. Brink, Alexander. 1949. A prospective view of forest-tree breeding in Wisconsin. Jour. For. 47:813-818.

2. Dominion Forest Service. 1949. Forest Fire losses in Canada, 1948. Dept. Mines and Resources; Canada. 9 pp.

3. Heimburger, C. C. 1949. Tree breeding research and its application. Canadian Pulp and Paper Association, Woodlands Sec. Index No. $1026(\mathrm{~F}-2)$.

4. Johnson, L.P.V. 1939. The breeding of forest trees. For. Chron. 15: 139-151.

5. Lindquist, Bertil. 1948. Genetics in Swedish forestry practice. The Chronica Botanica Co. Waltham, Mass. 173 pp.

6. National Research Council of Canada. 1950. Proceedings of the TwentySecond Meeting of the Subcommittee on Forest-tree Breeding of the Associate Committee on Forestry, Ottawa.

7. Schreiner, E.J. 1950. Genetics in relation to forestry. Jour. For. 48: 33-38.

8. Stockwell, Palmer and F. I. Righter. 1947. Hybrid forest trees. U.S. Dept. Agr. Yearbook of Agriculture, 1943-1947: 465-472. 